\title{
How does internet use affect ecological footprint?: An empirical analysis for $\mathrm{G} 7$ countries
}

\author{
Aslı Özpolat ${ }^{1}$
}

Received: 16 June 2020 / Accepted: 9 November 2021 / Published online: 2 December 2021

(c) The Author(s), under exclusive licence to Springer Nature B.V. 2021

\begin{abstract}
The study aims to search the effects of internet usage on the environment degradation in relation to technological revolutions. In this respect, G-7 countries are selected as the sample group. The link between environmental degradation and internet use in G7 countries is examined for the period from 1990 to 2015 with using panel data methodology by using AMG (Augmented Mean Group) estimator and heterogeneous panel causality. As a result of the panel results; it is found that the impact of internet usage on environmental degradations is negative. In addition, energy use and GDP per capita increase environmental degradations as trade openness and financial development impact on environmental degradations is meaningless. According to the panel causality analysis, the existence of a bidirectional causality relationship between energy use, internet use and ecological footprint. In additions, one-way causality relationship between GDP, trade, financial development index and ecological footprint is obtained.
\end{abstract}

Keywords Ecological footprint $\cdot$ Internet use $\cdot$ Environmental degradations $~ C$ Crosssectional dependence

\section{Introduction}

It is known that Information and Communication Technologies (ICT) has contributed significantly to development and growth within the scope of communication, productivity and research activities. With the added value created by high-tech products gaining considerable importance, the impact of the establishment of the infrastructure of information communication technology, expansion of the use of information technology, the increase in exports of goods and services in information communication technologies and the sustainability of growth and development cannot be ignored. In addition to the emergence of new production techniques, when developments in information and communication technology, laborsaving machines and productivity have increased, disadvantages such as global warming, pollution and health problems have also emerged. The Global Warming

Aslı Özpolat

asliozpolat@gmail.com

1 Department of Management and Organization, Oguzeli VSH, University of Gaziantep, Gaziantep, Turkey 
of $1.5{ }^{\circ} \mathrm{C}$ (2018) report indicates that global climate change is higher than expected level. For instance, global temperature has reached $0.1^{\circ} \mathrm{C} / 0.3^{\circ} \mathrm{C}$ above the levels of last period. While it is clear that energy is triggering economic growth, the minimization of $\mathrm{CO} 2$ emissions from energy use is stated in many reports and agreements, particularly in the Paris Climate Agreement (2015). It is particularly important to control the use of oil, coal and gas, which are clearly stated to cause climate change (Cai et al., 2018: 1001). In order to eliminate these disadvantages, various studies carry out to activate fields such as green technology and green information technologies. However, there is no consensus on the level of impact of these rapid developments and innovations on information technologies. According to the Green and Smarter Report (OECD, 2010), the environmental impact of ICT increases relatively as the use of the Internet and other ICT tools becomes widespread. Therefore, it is important that ICT manufacturers develop products that minimize environmental impacts. Similarly, SMART 2020-Report indicates that greenhouse gas emissions will be reduced with using ICT by $16.5 \%$ in 2020 . According to 2007 data, ICT accounts for approximately $2 \%$ of the carbon footprint. On the contrary, of this, ICT products and ICT enable products are usually made of environmentally harmful materials, which are harmful chemical elements. When the computer system includes around many different materials (Shabani, Shahnazi, 2019:1065) consider, determining the environmental effects of ICT appears to be important. Therefore, as mentioned earlier, there is no general view on the the link nexus ICT and its environmental contribution and environmental deteriorations. When the empirical studies are researched, the relationship nexus ICT and carbon emissions in economic literature includes two opposite approaches and these opposite approaches are shaped by three different outcome. In the first approach, it is stated that ICT will reduce energy use and thus make a positive contribution to the environment. ICT-supported solutions have a positive impact on the environment by decreasing greenhouse gas emissions. For example, number of e-mail sent reduces paper usage and contributes positively to the environment. Similarly, e-commerce and e-banking practices reduce environmental damage (Bekaroo et al., 2016: 1581). According to this effect, which is expressed as a substitution effect, operations made over the internet reduce energy usage and carbon emissions (Shabani \& Shahnazi, 2019: 1065). Therefore, the positive effects of human behaviors on the environment can be maximized by supporting ICT and ICT-supported products (Elliot, 2011), ICT will improve the environmental quality with the development of smart cities, transportation system, network system, industrial production operations and energy-efficient products (Higon et al., 2017: 85). Therefore, this effect is expected to occur especially in the services and transportation sector (Shabani \& Shahnazi, 2019: 1065). In addition, the above-mentioned areas of use are internet-supported. Looking at the rate of internet usage in the world, it is estimated that global internet usage will reach $53.6 \%$ (or 4.1 billion people) by the end of 2019. Considering that the rate of Internet expansion will increase in future, it is important to determine the environmental impacts arising from internet use. In the second approach, it is stated that ICT affects environment negatively as the production, and use of ICT will require energy use. The two effects explain these negative effects. According to the first effect defined as the use effect, energy production and $\mathrm{CO} 2$ emissions are increasing while ICT machines and equipment are produced. For example, in 2008 energy using for ICT equipment is $168 \mathrm{GW}$. According to Zhang and Liu (2015), it is expected that the energy using will be $430 \mathrm{GW}$ in 2020 . Moreover, The widespread use of ICTs, which are responsible for approximately $2 \%$ of global carbon emissions, leads to a raise in the emission of greenhouse gas emissions, which is expected to increase from $1.3 \%$ in 2002 to $2.3 \%$ in 2020 (GeSI, 2012). The last effect of this approach, which states that ICT will increase energy consumption and carbon emission, is the costing 
effect related to the demand increasing effect of ICT on other products. Accordingly, widespread use of ICT will increase the demand for products in other sectors and thus increase energy usage and carbon emissions in these sectors. (Shabani \& Shahnazi, 2019: 1065). In general, ICT investments have two conflicting consequences on energy consumption. The first of these is the decrease in energy consumption with the formation of new technological production processes and the replacement of old technology with new technology. Therefore, this innovation process reduces the energy consumption. The second result is the presence of ICT equipment requires the use of energy (Cho et al, 2007: 4730). Whether these contradictory results depend on the level of development of countries and how the use of ICT will have an impact on environment in future includes controversial findings (OECD, 2010: 40).

The main purpose of the paper is to research the link between Internet use and environmental degradation. This relation examines with the panel estimator (Augment Mean Group) for the period from 1990 to 2015 . Moreover, we analyze causality link internet use and ecological footprint by using heterogeneity panel causality test. The motivation of the study is to observe the improvement of ICT product and ICT product use. In addition, G7 countries are world leaders in the use of ICT and ICT-supported products. Moreover, these countries are among the countries with the highest share in internet use. The impact of these countries on the environment due to their industrial investments and the use of tools that trigger economic growth is an incontrovertible level. In addition, G7 countries are among the countries with the highest carbon emissions. Therefore, when the ICT priorities of G7 countries are examined in "G7 ICT and Industry Ministers Declaration" report (2017), it is stated that ICT investments should be given priority in technology, innovation and global economy scale. ICT infrastructure works and investments, which will be developed in order to support one of the seventeen sustainable development objectives of industrialization, innovation and infrastructure, are expected to provide high value-added outputs for the future of the economy. In addition, Table 1 contains the ICT Development Index (IDI). By using IDI, the comparison can be made among countries and over time.

According to Table 1, the highest IDI index belongs to England with a value of 8.65. The lowest value belongs to Italy with 7.04. However, in general, all countries are well above the world average. Therefore, to examine the environmental alterations arising from the use of the Internet is crucial. In addition, it is important to identify the contribution of ICT and the Internet to environmental policies.

Environmental degradations can be measured not only by $\mathrm{CO} 2$ emissions but also by the ecological footprint that is a broader concept. The ecological footprint measures how much nature people need to produce goods and services that they use to survive. While the earth's ecological footprint was 1 earth in 1970, it was 1.75 earth in 2018. It means that equivalent of 1.75 Earths is used by humanity for the resources and the waste (Global Footprint Network, 2019). In addition, ecological footprint is an important variable in determining the effect of bio capacity. Therefore, considering the necessity of measuring environmental damages not only with $\mathrm{CO} 2$ emissions but

Table 1 ICT Development Index for G7

\begin{tabular}{lcccccccc}
\hline Countries & USA & UK & Italy & Canada & Japan & France & Germany & Average for all Countries \\
\hline $\begin{array}{l}\text { ICT Development } \\
\text { Index }\end{array}$ & 8.18 & 8.65 & 7.04 & 7.64 & 8.43 & 8.24 & 8.39 & 5.11 \\
\hline
\end{tabular}

References: ITU World Telecommunication/ICT Indicators database, 2019 
also with ecological footprint data, in this study, ecological footprint was used instead of $\mathrm{CO} 2$ emissions. From this view, the models have been estimated using yearly data from 1990 to 2015 for G7 countries, which are Canada, Japan, Italy, USA, UK, France and Germany. By using the variables above, the dynamic relationship between the series has been analyzed using the Augment Mean Group (AMG), estimator and the heterogeneity panel causality test. The major input of the study into the existing literature is as follows:

i. According to our literature research, although studies on ICT and $\mathrm{CO} 2$ emissions have been widely reported in the literature, the link between internet using and ecological footprint in G7 countries is investigated in the paper.

ii. The model in the study has been estimated using the panel methods including the existence of Cross-Sectional Dependency so that the estimation could give more meaningful results than using other methods, which ignore the Cross-Sectional Dependency.

iii. In conclusion section, some political suggestions have been offered based on the results.

From point of this view, the study frame is generally prepared as the following; Sect. 1 is reviewed the studies and findings on environmental quality and determination as two sub-sections which are the relationship between internet use and environmental degradation. Section 2 includes methodological approach and data brief. Finally, the results are given in Sect. 3 and based on the results, conclusions and policy recommendations are in Sect. 4.

\section{Literature review}

When the literature about environmental degradation is evaluated, it can be seen that the possible link nexus economic growth, $\mathrm{CO} 2$ emissions, energy consumption (Asongu, 2017: 354), financial development and trade have been mostly studied (see for example, Grossman \& Krueger, 1991; Lucas et al., 1992; Shafik, 1994; Wyckoff \& Roop, 1994; Stern et al., 1996; Ekins, 1997; Suri \& Chapman, 1998; Stern, 1998; Stern, 2004; Heil \& Selden, 1999; Liu, 2004; Dinda, 2004; Jumbe, 2004; Dinda \& Coondoo, 2006; Soytas et al., 2007; Coondoo \& Dinda, 2008; Managi and Jena, 2008; Apergis \& Payne, 2009; Odhiambo, 2009a, 2009b; Iwata et al., 2010; Ozturk \& Acaravci, 2010; Menyah \& Wolde-Rufael, 2010; Saboori et al., 2012; Iwata et al., 2012; Tiwari et al., 2013; Shahbaz et al., 2013a, 2013b; Al-Mulali et. Al, 2015a; Bölük \& Mehmet, 2015; Baek, 2015; Atasoy, 2017a, 2017b). In the literature section, studies on environmental economics are divided into two parts. In the first part, the studies empirically examining the nexus between ICT and environmental deterioration and in the last part the relationship between internet use and environmental deterioration are given. In empirical studies on environmental degradations, $\mathrm{CO} 2$ is represented by emissions or ecological footprint. To the best of our knowledge, there are no studies describing environmental quality as an ecological footprint in studies examining on ICT, Internet use and their impact. 


\subsection{ICT and environmental degradations}

Although studies on ICT and environmental degradations are limited, empirical studies in this field have become important with the expansion of ICT's uses and technological advances. Studies indicating that environmental pollution will decrease with the use of ICT gain weight among the existing studies. Moyer and Hughes (2012), indicate a negative link between ICT and general carbon emissions however, the net impact of ICT has limitation. In their study, building and exploring scenarios to estimate ICT impact have been created. They found that ICT has a positive potential to reduce carbon emissions with two way. Firstly, ICT can cause reduction in energy intensity, and secondly, it can increase production of new renewable energy forms. However, ICT can affect environmental quality by rising GDP. Cho et al. (2007) states the increase in ICT investments in South Korea increased the energy intensity in the production and services sector. Takase and Murota (2004), pointed out that IT investments on energy conversation cause energy-savings in Japan and England. In both countries, the inverse relationship between IT and energy density was obtained. Similarly, Higon et al. (2017) found that an inverted-U relationship between ICT and carbon emission. In addition, unlike developing countries, $\mathrm{CO} 2$ emissions decrease in developed countries as ICT development level increases. Asongu et al. (2017) found that ICT effects environmental quality positively. Therefore, ICT invest and infrastructure can be addressed to surround environmental quality in Sub-Saharan African Countries by using GMM. Erdmann and Hilty (2010) claiming that ICT reduce greenhouse gas emissions. In additions, they state that ICT is one of the key factor in reducing energy costs by increasing energy-saving and reducing the negative impacts on climate change. Similarly, Ishida (2015) also stated that ICT increases economic growth in Japan in the 1980-2010 period and caused a decrease in energy use. Thus, the environmental pressure of energy use is alleviated. Bastida et al. (2019) found that the use of household ICT reduced household energy consumption by $0 \%$ to $5 \%$ in EU-28 countries. In addition, it was reported that household ICT use contributed $0.23 \%$ to $3.3 \%$ to the EU CO2 e-reduction target. Zhang and Liu (2015) studied on the impact of ICT on carbon emissions in China and concluded that the use of information communication technology reduces carbon emissions through energy efficiency gains. Cai et al. (2013) stated that the impact of IT on environmental sustainability is to contribute to the cost reduction and comparative advantage of firms in their studies on China. Moreover, by investing in IT and IT-supported systems and products, environmentally friendly competitiveness can be achieved. On the other hand, Salahuddin and Alam (2015) have concluded that ICTs are pushing for increased energy use which plays a key role in the emission of global carbon emissions. Sadorsky (2012) concluded that ICT effects electricity consumption positively in 19 developing countries. Similarly, Zang and Liu (2015) studies on the link nexus carbon emission and ICT with the STIRPAT model for China, and concluded that ICT helps reduce $\mathrm{CO} 2$ emissions. Webb et al. (2008) concluded that ICT applications will reduce carbon emissions to $7.8 \mathrm{Gt}$ CO2 by 2020. In addition, Lee and Brahmasrene (2014) found that there was a significant positive effect on the carbon emission of information communication technologies in ASEAN countries in 1991-2009. Shabani and Shahnazi (2019), which measures the impact of ICT on energy consumption and $\mathrm{CO} 2$ emissions as sectoral (agriculture, industry, services and transport), and the impact of ICT is positive on CO2 emissions in industry sector, while is negative on emissions in transportation sector in Iran for the period from 2002 to 2013. Contrary to these studies, there are also studies indicating 
that the use of ICT has a harmful effect on environmental quality. According to Bekaroo et al. (2016), use of ICT grow rapidly and this improvement has affected environmental quality negatively because of complex society problem with rebound effects on human. Fettweis and Zimmermann (2008) state that ICT systems cause 2\% CO2 emissions and will have a crucial role in air pollution in future. Raheem et al. (2019) concluded that ICT effects CO2 emission positively by using Pooled Mean Group analysis for G7 countries between 1990 and 2014. Supporting to this study, Khan et al. (2018) concluded that the use of ICT increases environmental degradations.

\subsection{Internet using and environmental degradations}

There is a high increase in electricity consumption in connection with information technologies (IEA, 2009), and intense pressure is put on energy demand by using of the internet, which is the most important variable of information communication technologies (Salahuddin et al., 2016). However, there are different views on the impact of internet use on energy demand and environment. Furthermore, studies investigating the effects of internet use on the environment are very limited. When the studies are examined in general, it is seen that there are conflicting results regarding the effects of internet usage on the environment. Romm (2002) states that the use of the Internet in the 1987-1996 period did not lead to an increase in electricity demand and caused energy efficiency. Sahuddin, Alam and Ozturk (2016), in their studies searching the possible link between carbon emission, internet use and growth for OECD countries between 1991 and 2012, concluded that internet use is not of a size that will affect environmental quality. However, it is also among the results of the study that internet usage will increase $\mathrm{CO} 2$ emissions in future. In addition, the study noted that ICT equipment of OECD countries should not only reduce the carbon footprint, but also benefit from ICT's emission reduction potential to reduce emissions in other sectors. Ozcan and Apergis (2017), using a panel test approach for 20 emerging economies during 1990-2015, found that internet access has a negative impact on air pollution. Therefore, according to study, ICT sector can be possible channel to reduce environmental degradations. Al-Mulali et al. (2015c) state internet use in developing countries reduces $\mathrm{CO} 2$ emissions. In addition to these studies, there are also studies where activities such as e-commerce and e-banking via the internet cause less energy use compared to operations that made by traditional methods. Accordingly, Toffel and Horvath (2004) indicate that wireless information technologies play a very important role in reducing negative environmental impacts. They also stated that wireless teleconference would be 1-3 times lower than that of business travel and that the negative pressures of information communication technologies on the environment were alleviated. Coroama et al. (2012), in their field study based on the use of substitutable information communication technologies instead of carbon intensive technologies, concluded that virtual participation in conferences was quite effective in reducing greenhouse gas emissions compared to traveling. Chavanne et al. (2015) state that teleconferencing decrease electricity use despite the physical counterpart. Matthews et al. (2002) concluded that online purchased books in the USA and Japan demand more energy than traditionally purchased books. Contrary to this study, Dost and Maier (2017) found that e-commerce in the residential and commercial sector will increase energy consumption in their studies between 1992 and 2005 for the US. Moreover, Gombier (2011) indicates that impact of internet use is unclear on ecological footprint. Because internet may extend the increase of energy demand of high-bandwidth content, servers and 
other ICT product. In addition, their findings show that internet's carbon footprint is higher than green gas emissions such as air travel.

\subsection{Ecological footprint, economic growth and energy consumption}

Asicı and Acar (2016) found that the EKC hypothesis is valid between ecological footprint and economic growth in their studies that conducted panel data analysis for 116 countries for the period of 2004-2008. Charfeddine and Mrabet (2017) conducted panel FMOLS analysis for MENA 15 countries in 1995-2007 and found that the EKC hypothesis was valid. Mrabet and Alsamara (2017) applied ARDL test for Qatar and concluded the validity of EKC hypothesis from 1980 to 2011. In contrast, Charfeddine (2017) examined the EKC hypothesis in Qatar during 1970-2015 and found that the EKC hypothesis was invalid. They also concluded that openness and urbanization in this country negatively affect the ecological footprint, whereas electricity consumption and financial development have a positive impact. Al-Mulali et al. (2015b) investigated the validity of the EKC hypothesis for 93 countries between 1980 and 2008, and concluded that the EKC hypothesis was invalid in low, lower middle income and invalid in higher income countries. In addition, energy consumption, urbanization and openness have a positive effect on the ecological footprint. Hassan et al. (2018) studied the long-term impact of economic growth and natural resources on the ecological footprint by using ARDL analysis for Pakistan between 1970 and 2014. The findings of the study suggest that the environmental Kuznets curve is supported. Similarly, Destek et al. (2018) between 1980 and 2013, they found that there was a U-shaped relationship between real income and ecological footprint in EU countries, and that openness and renewable energy reduced environmental degradation. In contrast, Aydin et al. (2019) found that the EKC hypothesis was invalid in their studies in which predicted by panel smooth transition regression model for 26 EU countries between 1990 and 2013.

\section{Model specification}

The main purpose of the study is the research the effect of internet usage on the environmental area. In order to investigate the effect of internet use (\% of population) on environment by using ecological footprint (gha per person) and compare relative relationship between GDP per capita (constant 2010 US\$), financial development (financial development index), trade openness (total trade share in GDP) and energy use (kg of oil equivalent per capita), the annual data have been collected for the period of 1990-2015 for G7 countries (Canada, France, Germany, Japan, Italy, UK and USA). The period of the paper is the main constraint of the paper because of data availability. It aims to overcome this limitation with the econometric method used. The panel model is formed as follows:

$$
\operatorname{InEF}_{i, t}=\alpha_{0}+\alpha_{1} \operatorname{InIU}_{i, t}+\alpha_{2} \operatorname{InENU}_{i, t}+\alpha_{3} \operatorname{INY}_{i, t}+\alpha_{4} \operatorname{InTR}_{i, t}+\alpha_{5} \operatorname{InFD} D_{i, t}+\varepsilon_{i, t}
$$

In the model, period is indicated by using $\mathrm{t}$, cross-section is indicated by using $\mathrm{i}$, and residual term is indicated by using $\varepsilon_{i, t}$. Moreover, $\operatorname{InEF_{i,t}}$ is $\log$ of ecological footprint, $\operatorname{InI} U_{i, t}$ is $\log$ of Individuals using the Internet, $\operatorname{InENU_{i,t}}$ is $\log$ of Energy use, $\operatorname{In} Y_{i, t}$ is $\log$ of GDP per capita, InTR ${ }_{i, t}$ is $\log$ of trade openness (\% of GDP), and $I n F D_{i, t}$ is $\log$ of financial development index. The data of Energy use, GDP per capita, Trade Openness, Individuals using the Internet were sourced from the World Development Indicators 2015 (World Bank), financial development index data were sourced from IMF, and ecological footprint was obtained from 
global footprint network. Since there are a limited number of empirical studies using ecological footprint in the literature as an indicator of environmental degradation, the effect of the variables in the model on the ecological footprint is not clear. In addition, the use of ecological footprints can give more effective results to express environmental degradation (Destek \& Okumus, 2019). For this, the ecological footprint is generally intended to fill the research gap in the literature. However, in general, when the literature is evaluated, the coefficients in the model, $\alpha_{1}, \alpha_{4}$ and $\alpha_{5}$ are not certain. However, $\alpha_{2}$ and $\alpha_{3}$ coefficients are expected to be positive and significant. Energy consumption is a factor to evaluate the environmental degradation, and the literature has been evaluated, the empirical findings generally indicate the positive relationship among the variables. The effect of trade openness can be significant and insignificant. Destek et al. (2018) state a negative link among variables in newly industrialized countries. On the contrary, Ozturk et al. (2016) state insignificant relationship among variables. In addition, the impact of financial development on ecological footprint is not clear also. Financial development index was developed by IMF and includes the data (depth, access and efficiency) related to financial institutions and financial markets. Destek et al. (2019) indicate a positive link between financial development and ecological footprint in EU countries.

In the analysis, it has been analyzed the impact of internet using on ecological footprint. Therefore, the cross-sectional dependence, which is frequently encountered in panel data analysis, was investigated by using CD Test. It is assumed that the breakdowns and changes occurring in the units in the panel data analysis are independent of each other, and the units do not affect each other. However, it is very unlikely that the panels created do not affect each other. Therefore, firstly, the dependency between the units should be investigated in the panel data analysis. This dependence between the units of the panel, called the Cross-Sectional Dependent, was estimated by using the CD test developed by Pesaran (2004) is calculated as follows:

$$
C D=\sqrt{\frac{2 T}{N(N-1)}}\left(\sum_{i=1}^{N-1} \sum_{j=i+1}^{N} \hat{\rho_{i j}}\right)
$$

In the model, $\mathrm{T}, \mathrm{N}$ and $\hat{\rho}$ indicates the time dimension, the cross-sectional dimension and $i j$ the binary OLS correlation sample estimate of the remains, respectively. Where the T value is small, and the $\mathrm{N}$ value is large, the $\mathrm{CD}$ test allows asymptotic standard normal distribution. Furthermore, the null hypothesis is established under asymptotic distribution, and the null hypothesis shows the slope of the coefficients in case of single or multiple fractures (Pesaran, 2004: 1-7). After determining the cross-sectional dependence and homogeneity, Augment Mean Group (AMG) panel estimator which is developed by Eberhardt and Bond (2009), Bond and Eberhardt (2013) has been used. These analyzes can be estimated in the presence of heterogeneity and cross-sectional dependence among countries. In addition, the series do not need to be equally stable and gives significance results under the structural breaks (Atasoy, 2017a, 2017b; Mercan \& Azer, 2013) Therefore, parameter estimation has been performed without unit root analysis. AMG approach includes three steps: In the first stage of the AMG test (1) numbers are modeled variables that are estimated to be first degree stationary with year dummies. Accordingly, the model is as follows:

$$
\Delta E F_{i, t}=\alpha_{0}+\alpha_{1} \Delta I U_{i, t}+\alpha_{2} \Delta E N U_{i, t}+\alpha_{3} \Delta Y_{i, t}+\alpha_{4} \Delta T R_{i, t}+\alpha_{5} \Delta F D_{i, t}+\sum_{t=2}^{T} P_{t}\left(\Delta D_{t}\right)+\varepsilon_{i, t}
$$

In the model, $\Delta D_{t}$ represents first-differences of dummy variable; $p_{t}$ is coefficient of dummy variable. At the second stage of the analysis, (Eq. 4) estimated $p_{t}$ parameter is counted in model as a common dynamic process $\left(\varphi_{t}\right)$. 


$$
\Delta E F_{i, t}=\alpha_{0}+\alpha_{1} \Delta I U_{i, t}+\alpha_{2} \Delta E N U_{i, t}+\alpha_{3} \Delta Y_{i, t}+\alpha_{4} \Delta T R_{i, t}+\alpha_{5} \Delta F D+d_{i}\left(\varphi_{t}\right)+\varepsilon_{i, t}
$$

Finally, the model parameters indicate the average over the panel. The model is as follows:

$$
\Delta E F_{i, t}-\varphi_{t}=\alpha_{0}+\alpha_{1} \Delta I U_{i, t}+\alpha_{2} \Delta E N U_{i, t}+\alpha_{3} \Delta Y_{i, t}+\alpha_{4} \Delta T R_{i, t}+\alpha_{5} \Delta F D+\varepsilon_{i, t}
$$

Then the causality relationship between variables has been estimated by Heterogeneous Granger Causality Test (Dumitrescu \& Hurlin, 2012). The test is written as follows:

$$
y_{i, t}=\alpha_{1}+\sum_{k-1}^{K} \gamma_{i}^{(k)} y_{i, t-k}+\varepsilon_{i, t}
$$

After the explaining the methods of the study, the summary of descriptive statistics with the average of the variables of G7 countries has been given in Table 2. According to summary of statistics, the mean of ecological footprint ranges from 0.77 in japan to 2.256 in USA. According to internet users, the highest value is belong to USA (1.419), and the lowest value is in Italy (0.834). USA has the maximum number (3.878) for energy use, while Italy has the least number (3.453). In case of GDP per capita, USA, Japan and Canada are the leading countries among G7. When variations are evaluated, japan has the lowest variations for ecological footprint. Canada, France and Germany have the lowest variations in energy use.

In addition to this, to investigate the multicollinearity, correlation analysis between variables has been estimated. The results are shown in Table 3.

According to the results, in general, it can be seen that the correlation rate between variables is below 50\%. Among the independent variables, the highest correlation level is seen between GDP per capita and trade openness. However, this effect is also below $50 \%$. There is a $42 \%$ correlation between energy use and energy ecological footprint, a $0.02 \%$ correlation between financial development and energy efficiency, and a 15\% correlation between financial development and trade openness. The lowest correlation has been obtained for financial development and energy efficiency. In general, when the data are evaluated, it can be said that there is no multicollineartiy problem among variables.

In addition to all these, the scatter plot between ecological footprint and internet usage is included in Fig. 1. Scatter plot is made to reveal the relationship between two variables.

In the figure, the reason for the relationship cannot be clearly seen, but information can be obtained about the variables acting together and the direction of the relationship. Accordingly, variables move together, and the relationship is strong. Figure represents panel results.

\section{Results and discussion}

In this part, empirical findings have been discussed. The standard panel data analysis assumes that there is no Cross-Section Dependence between the units that constitute the panel. That is, different countries have different structural parameters (economics functions, environmental functions, etc.) Accordingly, shocks in units do not affect other units. However, this assumption cannot always obtain results among units. Therefore, whether Cross-Section Dependence exists among the panel units should be estimated and if there is a dependency among the panel units, the test should consider using dependency to obtain 
Table 2 Descriptive Statistics

\begin{tabular}{|c|c|c|c|c|c|c|c|}
\hline Countries & & INEF & INENU & INFD & INIU & INTR & INY \\
\hline \multirow[t]{4}{*}{ Canada } & Mean & 2.141 & 3.901 & -0.133 & 1.351 & 1.819 & 4.636 \\
\hline & Maximum & 2.250 & 3.927 & -0.054 & 1.946 & 1.918 & 4.701 \\
\hline & Minimum & 2.048 & 3.876 & -0.316 & -0.442 & 1.693 & 4.547 \\
\hline & Std. Dev & 0.052 & 0.014 & 0.077 & 0.786 & 0.059 & 0.053 \\
\hline \multirow[t]{4}{*}{ France } & Mean & 1.671 & 3.605 & -0.184 & 1.058 & 1.708 & 4.577 \\
\hline & Maximum & 1.752 & 3.633 & -0.082 & 1.922 & 1.790 & 4.620 \\
\hline & Minimum & 1.547 & 3.563 & -0.353 & -1.277 & 1.601 & 4.512 \\
\hline & Std. Dev & 0.054 & 0.019 & 0.089 & 0.972 & 0.057 & 0.039 \\
\hline \multirow[t]{4}{*}{ Germany } & Mean & 1.708 & 3.609 & -0.145 & 1.183 & 1.791 & 4.586 \\
\hline & Maximum & 1.931 & 3.645 & -0.097 & 1.935 & 1.933 & 4.658 \\
\hline & Minimum & 1.597 & 3.577 & -0.272 & -0.900 & 1.609 & 4.509 \\
\hline & Std. Dev & 0.078 & 0.017 & 0.043 & 0.938 & 0.113 & 0.044 \\
\hline \multirow[t]{4}{*}{ Italy } & Mean & 1.656 & 3.453 & -0.186 & 0.834 & 1.673 & 4.540 \\
\hline & Maximum & 1.763 & 3.507 & -0.100 & 1.766 & 1.755 & 4.582 \\
\hline & Minimum & 1.480 & 3.382 & -0.401 & -1.755 & 1.531 & 4.489 \\
\hline & Std. Dev & 0.082 & 0.036 & 0.107 & 1.159 & 0.066 & 0.028 \\
\hline \multirow[t]{4}{*}{ Japan } & Mean & 0.707 & 3.582 & -0.141 & 1.104 & 1.369 & 4.630 \\
\hline & Maximum & 0.750 & 3.611 & -0.063 & 1.959 & 1.574 & 4.673 \\
\hline & Minimum & 0.649 & 3.535 & -0.245 & -1.692 & 1.204 & 4.580 \\
\hline & Std. Dev & 0.030 & 0.025 & 0.061 & 1.126 & 0.120 & 0.026 \\
\hline \multirow[t]{4}{*}{ UK } & Mean & 1.719 & 3.542 & -0.102 & 1.190 & 1.717 & 4.551 \\
\hline & Maximum & 1.822 & 3.588 & -0.027 & 1.963 & 1.792 & 4.620 \\
\hline & Minimum & 1.524 & 3.411 & -0.236 & -1.058 & 1.645 & 4.449 \\
\hline & Std. Dev & 0.087 & 0.045 & 0.059 & 0.977 & 0.039 & 0.059 \\
\hline \multirow[t]{4}{*}{ USA } & Mean & 2.256 & 3.878 & -0.096 & 1.419 & 1.389 & 4.645 \\
\hline & Maximum & 2.349 & 3.906 & -0.051 & 1.875 & 1.488 & 4.716 \\
\hline & Minimum & 2.098 & 3.832 & -0.242 & -0.105 & 1.296 & 4.550 \\
\hline & Std. Dev & 0.082 & 0.022 & 0.064 & 0.636 & 0.063 & 0.053 \\
\hline \multirow[t]{4}{*}{ Panel } & Mean & 0.930 & 3.901 & -0.133 & 1.351 & 1.819 & 4.636 \\
\hline & Maximum & 0.977 & 3.927 & -0.054 & 1.946 & 1.918 & 4.701 \\
\hline & Minimum & 0.889 & 3.876 & -0.316 & -0.442 & 1.693 & 4.547 \\
\hline & Std. Dev & 0.022 & 0.014 & 0.077 & 0.786 & 0.059 & 0.053 \\
\hline
\end{tabular}

statistically meaningful results. Considering these reasons, the Pesaran (2004) CrossSection Dependence (CD) test was estimated. After the determination of Cross-Section Dependence, AMG panel estimator and Heterogeneous panel causality test have been predicted. In the study, the link between ecological footprint, internet use, energy use, trade openness and financial development is examined for the period from 1990 to 2015 in G7 countries. Firstly, the cross-sectional dependence of the variables has been analyzed by the CD test. The results are shown in Table 4. No cross-sectional dependence is not accepted according to the all test results. It means a shock that occurs in an individual of the panel can affect the other individuals of the panel. Moreover, the homogeneity test results show that a country in the panel has a specific heterogeneity. Therefore, the existence of crosssectional dependence and heterogeneity among countries is accepted. 
Table 3 Correlation Analysis Results

\begin{tabular}{lllllll}
\hline Correlation & & & & & \\
\hline Probability & INEF & INENU & INFD & INIU & INTR & INY \\
INEF & 1.000000 & & & & \\
& - & & & & & \\
INENU & 0.425042 & 1.000000 & & & & \\
& 0.0000 & - & & & & \\
INFD & 0.101290 & 0.027431 & 1.000000 & & & \\
& 0.1823 & 0.7186 & - & & & \\
INIU & 0.058003 & 0.347206 & 0.242328 & 1.000000 & & \\
& 0.4458 & 0.0000 & 0.0012 & - & & \\
INTR & 0.274969 & 0.335818 & 0.154990 & 0.054537 & 1.000000 & \\
& 0.0002 & 0.0000 & 0.0406 & 0.4735 & - & \\
INY & 0.419075 & 0.426664 & 0.116671 & 0.203938 & 0.563947 & 1.000000 \\
& 0.0000 & 0.0000 & 0.1241 & 0.0068 & 0.0000 & - \\
\hline
\end{tabular}

Fig. 1 Scatter Plot for ecological footprint and internet use

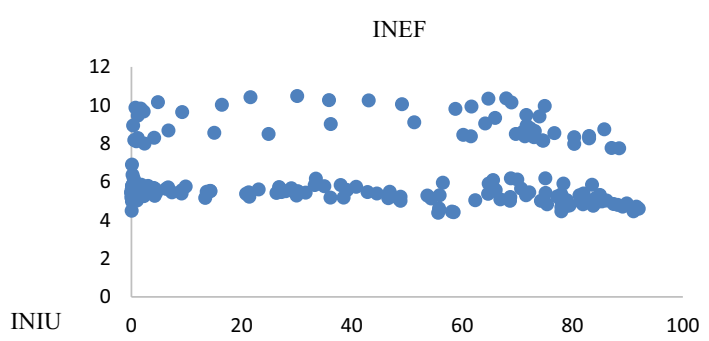

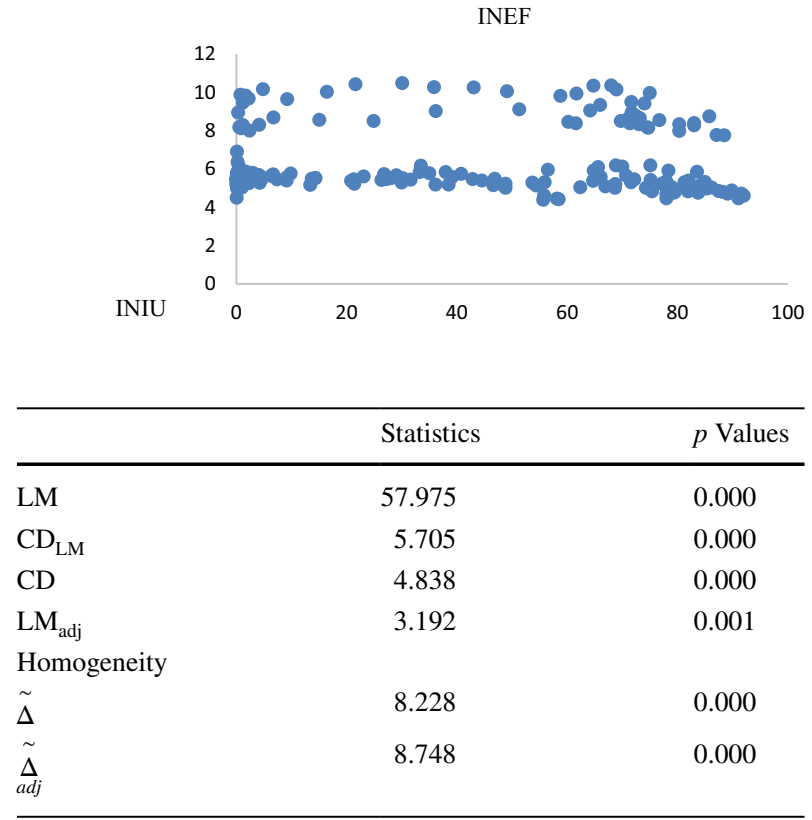

Table 4 Cross-sectional Dependency and Homogeneity

In the second stage of the analysis, the possible impact of internet use on variables is examined by using augment mean group estimator. Table 5 shows the test results.

According to the results shown in Table 5, the coefficient of energy use is positive in Canada, Germany, Italy, Japan, UK and USA. Meaning that energy use increases environmental degradation. Energy is still the key sources of the economic growth. Cai et. Al. (2018) indicate that G7 countries should develop energy-efficient technologies and use clean energy to sustain growth. Sarkodie and Adams (2018) indicate that renewable energy use can lead to decrease environmental pollution. However, fossil fuel energy use has an impact on environmental degradation positively. In addition, Cole (2006) notes that 
capital intensive industries have led to environmental pollution because of energy intensive. Therefore, it demands more energy to developed countries with the effect of factor endowment and trade liberalization. By directing this energy demand to renewable energy sources, a positive contribution will be made to the problem of environmental pollution. Internet use decreases environmental degradation in Germany, Italy, Japan, UK and USA. However, there is a positive relationship between internet use and ecological footprint in France. Thus, it can be said that developed countries generally generate energy-saving with internet use, which in turn, ICT. Financial development affects environmental degradation positively in Italy, Japan, UK and USA while trade openness has a negative impact on environmental degradation in Germany, unlike UK. According to Atil et al. (2019), financial development can effect to environmental degradation with two channels. Firstly, financial development increases energy consumption due to economic growth nexus. Therefore, more energy consumption may cause CO2 emissions. Moreover, Jensen (1996) states financial development can increase industrial activities and in turn industrial pollution. Secondly, financial development decreases $\mathrm{CO} 2$ emissions due to energy saved technologies such ICT enable products. It is called as technological effect. When the group panel estimation are considered, internet use decreases environmental degradations. However, energy use and GDP per capita increase environmental degradations. In the last stage of the analysis, the causal link among variables is examined by using heterogeneous panel causality test. The results are presented in Table 6 .

The results presented in Table 6 show a one-way causality from GDP per capita to ecological footprint and a bidirectional causality from GDP per capita to energy use. Therefore, the results are supported to growth hypothesis. Dinda and Coondoo (2006) indicate that the degree of trade openness specify the direction of causality between GDP per capita and environmental deterioration. It means that a bidirectional causality from GDP per capita to environmental deterioration occurs because of free access to energy supply in a highly open economy. Thus, there is a bidirectional causality from trade openness and financial development to ecological footprint. Finally, there is a unidirectional causality between ecological footprint and internet use. This result shows that the internet use has an impact on ecological footprint. Therefore, the causal link can be form as follows: energy consumption can lead to more internet use and internet use decrease environmental degradation.

Table 5 Estimator Results of Cointegration

\begin{tabular}{|c|c|c|c|c|c|}
\hline & INENU & INFD & INIU & INY & INTR \\
\hline Canada & $0.881^{*}$ & -0.042 & 0.008 & 0.552 & -0.090 \\
\hline France & 0.033 & 0.156 & $0.026 * * *$ & $0.774 * *$ & -0.014 \\
\hline Germany & $0.523 * * *$ & 0.067 & $-0.036^{* * *}$ & $0.243^{*}$ & $0.152 * *$ \\
\hline Italy & $0.375^{* *}$ & $0.173 * *$ & $-0.026 * * *$ & $0.876^{* * *}$ & 0.098 \\
\hline Japan & $0.853 * * *$ & $0.371 * *$ & $-0.023 * *$ & $0.457^{*}$ & 0.100 \\
\hline UK & $1.106^{* *}$ & $0.702 * *$ & $-0.052 * *$ & $-0.702 *$ & $-0.052 * *$ \\
\hline USA & $0.257 * * *$ & $0.184 * *$ & $-0.023 * *$ & $0.174 * *$ & 0.067 \\
\hline Panel & $0.532 * * *$ & 0.108 & $-0.306^{* * *}$ & $0.408 * * *$ & -0.041 \\
\hline
\end{tabular}

$*$, ** and *** indicates statistical significance at 10,5 and $1 \%$ level, respectively 
Table 6 The Heterogeneous Panel Causality Test Results

\begin{tabular}{|c|c|c|}
\hline Null Hypothesis: & W-Stat & Prob \\
\hline INENU $\rightarrow$ INEF & 5.80964 & 0.0587 \\
\hline $\mathrm{INEF} \rightarrow \mathrm{INENU}$ & 6.73472 & 0.0087 \\
\hline $\mathrm{INFD} \rightarrow \mathrm{INEF}$ & 8.05922 & 0.0002 \\
\hline $\mathrm{INEF} \rightarrow \mathrm{INFD}$ & 2.20335 & 0.3306 \\
\hline INIU $\rightarrow$ INEF & 5.68964 & 0.0726 \\
\hline $\mathrm{INEF} \rightarrow \mathrm{INIU}$ & 5.50722 & 0.0988 \\
\hline $\mathrm{INTR} \rightarrow \mathrm{INEF}$ & 6.90847 & 0.0057 \\
\hline $\mathrm{INEF} \rightarrow \mathrm{INTR}$ & 4.82901 & 0.2661 \\
\hline $\mathrm{INY} \rightarrow \mathrm{INEF}$ & 6.90766 & 0.0057 \\
\hline $\mathrm{INEF} \rightarrow \mathrm{INY}$ & 3.03920 & 0.7572 \\
\hline $\mathrm{INFD} \rightarrow \mathrm{INENU}$ & 7.91583 & 0.0004 \\
\hline INENU $\rightarrow$ INFD & 2.45814 & 0.4410 \\
\hline $\mathrm{INIU} \rightarrow \mathrm{INENU}$ & 5.19258 & 0.1613 \\
\hline INENU $\rightarrow$ INIU & 1.38009 & 0.0938 \\
\hline INTR $\rightarrow$ INENU & 14.7031 & 0.0000 \\
\hline INENU $\rightarrow$ INTR & 4.88862 & 0.2463 \\
\hline $\mathrm{INY} \rightarrow \mathrm{INENU}$ & 10.9928 & 2.E-09 \\
\hline $\mathrm{INENU} \rightarrow \mathrm{INY}$ & 2.19958 & 0.3291 \\
\hline INIU $\rightarrow$ INFD & 10.8664 & 4.E-09 \\
\hline $\mathrm{INFD} \rightarrow \mathrm{INIU}$ & 6.94121 & 0.0053 \\
\hline $\mathrm{INTR} \rightarrow \mathrm{INFD}$ & 3.20493 & 0.8591 \\
\hline $\mathrm{INFD} \rightarrow \mathrm{INTR}$ & 3.05470 & 0.7666 \\
\hline $\mathrm{INY} \rightarrow \mathrm{INFD}$ & 1.89706 & 0.2239 \\
\hline $\mathrm{INFD} \rightarrow \mathrm{INY}$ & 4.14285 & 0.5706 \\
\hline INTR $\rightarrow$ INIU & 3.45133 & 0.9856 \\
\hline INIU $\rightarrow$ INTR & 6.52432 & 0.0140 \\
\hline $\mathrm{INY} \rightarrow \mathrm{INIU}$ & 3.33640 & 0.9417 \\
\hline $\mathrm{INIU} \rightarrow \mathrm{INY}$ & 6.63858 & 0.0108 \\
\hline $\mathrm{INY} \rightarrow \mathrm{INTR}$ & 11.1298 & 1.E-09 \\
\hline $\mathrm{INTR} \rightarrow \mathrm{INY}$ & 5.99058 & 0.0419 \\
\hline
\end{tabular}

\section{Conclusion and policy implications}

In the study, to search the effect of internet use on ecological degradations and to compare the relationship between energy uses, growth, financial development and trade openness for the period from 1990 to 2015 in G7 countries is aimed. For this purpose, the relationship among variables examines with second generations panel data methodologies, which are AMG estimators and panel causality test. These methods give an advantage under crosssectional dependence and heterogeneity. According to AMG test panel results, internet use decreases ecological footprint. A $1 \%$ increase in internet usage reduces environmental degradation by $0.30 \%$. It means Internet use makes a positive contribution to environmental quality. However, energy use and GDP per capita increase environmental degradations. Accordingly, a $1 \%$ increase in GDP per capita increase the ecological footprint by $0.40 \%$, while $1 \%$ increase in energy use increase the ecological footprint by $0.53 \%$. When the results evaluated for individuals, internet use decreases environmental degradation in 
Germany, Italy, Japan, UK and USA. The coefficient of energy use is positive in Canada, Germany, Italy, Japan, UK and USA. Meaning that energy use increases environmental degradation. Financial development has an impact on environmental degradation positively in Italy, Japan, UK and USA while trade openness has a negative impact on environmental degradation in Germany, unlike UK. Causality test results show that there is a oneway causality from GDP per capita to ecological footprint and a one-way causality from GDP per capita to energy use. The evidence for causality from trade openness and financial development to ecological footprint has been obtained. Finally, there is a bidirectional causality between ecological footprint and internet use.

This study can support economic institutions in reviewing their procedures by evaluating the G7 countries using the Lucas critique on the use of environmentally friendly products. From the empirical results, the following policies can be predicted to control environmental degradation. With the main purpose of the study, we focus on the impact of internet using on environment degradations, and the policy implications are mostly based on this nexus. G7 countries use internet and internet related services such as tele-conferences, e-commerce and e-banking frequently. Therefore, to reduce environmental degradation, individual ICT product and ICT enable product use can be supported, and ICT sector can be subsidize. ICT-supported products that can have a positive impact on climate change are expressed as follows (Güngör et al., 2010:30). ICT devices that make better use of energy, dematerialization and smart technologies (logistics, trade, buildings, etc.). ICT has a great impact on the use and development of environmentally friendly products. Considering the recent developments (Covid-19), digitalization seems inevitable. Therefore, it is important to develop policies that reduce emissions and eliminate the increasing effects of ICT's energy demand. Moreover, countries strength the policy to support green ICT technology. As a summary, these policy implications supported ICT can be created domino effect to transfer developing countries to control emissions and provide energy use effectively.

\section{References}

Acaravc1, A., \& Ozturk, I. (2010). On the relationship between energy consumption, CO2 emissions and economic growth in Europe. Energy, 35(2010), 5412-5420.

Al-Mulali, U., Saboori, B., \& Öztürk, I. (2015a). Investigating the environmental Kuznets curve hypothesis in Vietnam. Energy Policy, 76, 123-131.

Al-Mulali, U., Ting, L. S., \& Ozturk, I. (2015c). The global move toward internet shopping and its influence on pollution: An empirical analysis. Environmental Science and Pollution Research, 22(13), 9717-9727.

Al-Mulali, U., Weng-Wai, C., Sheau-Ting, L., \& Mohammed, A. H. (2015b). Investigating the environmental kuznets curve (EKC) hypothesis by utilizing the ecological footprint as an indicator of environmental degradation. Ecological Indicators, 48, 315-323.

Apergis, N., \& Payne, J. E. (2009). CO2 Emissions, energy usage, and output in central America. Energy Policy, 37(8), 3282-3286.

Apergis, N., \& Payne, J. E. (2010). A panel study of nuclear energy consumption and economic growth. Energy Econ., 32(3), 545-549.

Aşıc1, A. A., \& Acar, S. (2016). Does income growth relocate ecological footprint? Ecological Indicators, $61,707-714$

Asongu, S. A. R., Le, S., \& Biekpe, N. (2017). Environmental degradation, ICT and inclusive development in sub-Saharan Africa. Energy Policy, 111(2017), 353-361.

Atasoy, B. S. (2017b). Testing the environmental Kuznets curve hypothesis across the US: Evidence from panel mean group estimators. Renewable and Sustainable Energy Reviews, 77, 731-747.

Atasoy, S. B. (2017a). Testing the environmental Kuznets curve hypothesis across the U.S.: Evidence from panel mean group estimators. Renewable and Sustainable Energy Reviews, 77, 731-747. 
Atil, A. Bouheni, F. B., Lahiani, A., Shahbaz, M. (2019). Factors influencing CO2 Emission in China: A nonlinear autoregressive distributed lags investigation. MPRA Paper No: 91190

Aydın, C., Esen, Ö., \& Aydın, R. (2019). Is the ecological footprint related to the Kuznets curve a real process or rationalizing the ecological consequences of the affluence? Evidence from PSTR approach. Ecological Indicators, 98, 543-555.

Baek, J. (2015). A panel cointegration analysis of CO2, emissions, nuclear energy and income in major nuclear generating countries. Applied Energy, 145, 133-138.

Bastida, L., Cohen, J. J., Kollmann, A., Moya, A., \& Reichl, J. (2019). Exploring the role of ICT on household behavioral energy efficiency to mitigate global warming. Renewable and Sustainable Energy Reviews, 103(2019), 455-462.

Bekaroo, G., Bokhoree, C., \& Pattionson, C. (2016). Impacts of ICT on the natural ecosystem: A grass root analysis for promoting socio-environmental sustainability. Renewable and Sustainable Energy Reviews, 57, 1580-1595.

Bölük, G., \& Mehmet, M. (2015). The renewable energy, growth and environmental Kuznets Curve in Turkey: An ARDL approach. Renewable and Sustainable Energy Reviews, 52, 587-595.

Bond, S., \& Eberhardt, M. (2013). Accounting For Unobserved Heterogeneity in Panel Time Series Models. University Of Oxford, Mimeo.

Breusch, T., \& Pagan, A. (1980). The Lagrange multiplier test and its applications to model specification in econometrics. Review of Economic Studies, 47(1), 239-253.

Cai, S., Chen, X., \& Bose, I. (2013). Exploring the role of IT for environmental sustainability in China: An empirical analysis. International Journal of Production Economics, 146(2013), 491-500.

Cai, Y., Sam, C. Y., \& Chang, T. (2018). Nexus between clean energy consumption, economic growth and CO2 emissions. Journal of Cleaner Production, 182, 1001-1011.

Charfeddine, L. (2017). The impact of energy consumption and economic development on ecological footprint and $\mathrm{CO} 2$ emissions: Evidence from a Markov switching equilibrium correction model. Energy Economics, 65, 355-374.

Charfeddine, L., \& Mrabet, Z. (2017). The impact of economic development and social-political factors on ecological footprint: A panel data analysis for 15 MENA Countries. Renew Sust Energ Rev, 76, $138-154$.

Chavanne, X., Schinella, S., Marquet, D., Frangi, J. P., \& Masson, S. L. (2015). Electricity consumption of telecommunication equipment to achieve a tele-meeting. Apply Energy, 137, 273-281.

Cho, Y., Lee, J., \& Kim, T. (2007). The impact of ICT investment and energy price on industrial electricity demand: Dynamic growth model approach. Energy Policy, 35, 4730-4738.

Cole, M. A. (2006). Does trade liberalization increase national energy use? Economics Letters, 92(2006), $108-112$.

Coondoo, D., \& Dinda, S. (2008). The carbon dioxide emission and income: A temporal analysis of crosscountry distributional patterns. Ecological Economics, 65, 375-385.

Coroama, V. C., Hilty, L. M., \& Birtel, M. (2012). Effects of internet-based multiple-site conferences on greenhouse gas emissions. Telematics and Informatics, 29, 362-374.

Destek, M. A., \& Okumus, İ. (2019). Does pollution haven hypothesis hold in newly industrialized countries? Evidence from ecological footprint. Environmental Science and Pollution Research, 26(2019), 23689-23695.

Destek, M. A., Ulucak, R., \& Dogan, E. (2018). Analyzing the environmental Kuznets curve for The EU countries: The role of ecological footprint. Environmental Science and Pollution Research, 25(29), 29387-29396.

Dinda, S. (2004). Environmental Kuznets curve hypothesis: A survey. Ecological Economics, 49, 431-455.

Dinda, S., \& Coondoo, D. (2006). Income and emission: A panel data-based cointegration analysis. Ecological Economics, 57, 167-181.

Dost, F., \& Maier, E. (2017). E-Commerce effects on energy consumption: A multi-year ecosystem-level assessment. Journal of Industrial Ecology, 22(4), 799-812.

Dumitrescu, E. I., \& Hurlin, C. (2012). Testing For granger non-causality in heterogeneous panels. Economic Modelling, 29, 1450-1460.

Eberhardt M, Bond, S (2009) Cross-Section Dependence in Nonstationary Panel Models: A Novel Estimator

Ekins, P. (1997). The Kuznets curve for the environment and economic growth: Examining the evidence. Environment and Planning A, 29(5), 805-830.

Elliot, S. (2011). Transdisciplinary perspectives on environmental sustainability: A resource base and framework for IT-enabled business transformation. MIS Quarterly, 35(1), 197-236.

Erdmann, L., \& Hilty, L. M. (2010). Scenario analysis; exploring the macroeconomic impacts of information and communication technologies on greenhouse gas emissions. Journal Industrial Ecology, 14, 826-843. 
esaran, M.H. (2007). A simple panel unit root test in the presence of cross-section dependence. Journal of Applied Economics, 22(2), 265-312.

Fettweis G., Zimmermann E. (2008) ICT Energy consumption-trends and challenges. In: The11th International Symposium on Wireless Personal Multimedia Communications (WPMC2008); 2, 6.

G7 ICT and Industry Ministers' Declaration (2017). Making the next production revolution inclusive, open and secure. Italy Retrieved From https://TEAMDIGITALE.GOVERNO.IT/UPLOAD/DOCS/2017/10/ DECLARATION_AND_ANNEXES_FINAL_26_09_2017.PDf

Gesi (2012). Smart 2020: Enabling the low carbon economy in the information age. Retrieved From https:// Www.Theclimategroup.Org/Sites/Default/Files/Archive/Files/Smart2020Report.Pdf

Global Footprint Network, (2019). National footprint accounts, ecological footprint. Retrieved From. http:// Data.Footprintnetwork.Org

Gombiner, J. (2011). Carbon foot printing the internet. The Journal of Sustainable Development., 5(1), 119-124.

Grossman G. M., Krueger A. B. (1991). Environmental impacts of a North American Free Trade Agreement. NBER Working Paper, 3914, Washington

Güngör, M., Saygı, N. Bolat, A. Çaycı D., Tekin M. A. (2010). Yeşil Bilişim. Retrieved From https://www.btk. gov.tr/uploads/pages/slug/yesil-bilisim.pdf

Hassan, S. T., Xia, E., Khan, H. N., \& Shah, S. M. A. (2018). Economic growth, natural resources, and ecological footprints: Evidence from Pakistan. Environmental Science and Pollution Research, 26(3), 2929-2938.

Heil, M. T., \& Selden, T. M. (1999). Panel stationarity with structural breaks: Carbon emissions and GDP. Applied Economic Letters, 6, 223-225.

Higon, D., Gholami, R., \& Shirazi, F. (2017). ICT and environmental sustainability: A global perspective. Telematics and Informatics., 34(2017), 85-95.

IPCC, (2018). Global Warming of $1.5^{\circ} \mathrm{C}$ Report, Retrieved From https://Www.Ipcc.Ch/Site/Assets/Uploads/ Sites/2/2019/06/SR15_Full_Report_High_Res.Pdf

Ishida, H. (2015). The effect of ICT development on economic growth and energy consumption in Japan. Telematics and Informatics, 32, 79-88.

ITU (2019). World Telecommunication/ICT Indicators Database. Retrieved From https://Www.Itu.Int/En/ITUD/Statistics/Pages/Publications/Wtid.Aspx

Iwata, H., Okada, K., \& Samreth, S. (2010). Empirical study on the environmental Kuznets curve for Co2, In France: The role of nuclear energy. Energy Policy, 38(8), 4057-4063.

Iwata, H., Okada, K., \& Samreth, S. (2012). Empirical study on the determinants of CO2 emissions: Evidence from OECD Countries. Applied Economics, 44(27), 3513-3519.

Jumbe, C. B. (2004). Cointegration and causality between electricity consumption and GDP: Empirical evidence from Malawi. Energy Economics, 26(1), 61-68.

Khan, D. N., Baloch, M. A., Saud, S., \& Fatima, T. (2018). The level Of ICT On CO2 emissions in emerging economies: Does the level of income matters? Environmental Science and Pollution Research, 25(23), 22850-22860.

Lee, J. W., \& Brahmasrene, T. (2014). ICT, CO2 emissions and economic growth: Evidence from a panel of ASEAN. Global Economic Review, 43, 93-109.

Lucas, R., Wheeler, D. and Hettige, H., (1992). Economic development, environmental regulation, and international migration of toxic industrial pollution. In: Low, P. (Ed.) International Trade and Environment. Discussion Papers, 159, World Bank, Washington, DC.

Matthews, H. S., Williams, E., Tagami, T., \& Hendrickson, C. T. (2002). Energy implications of online book retailing in the United States and Japan. Environmental Impact Asses, 22(5), 493-507.

Menyah, K., \& Wolde-Rufael, Y. (2010). Energy consumption, pollutant emissions and economic growth in South Africa. Energy Economics, 32(6), 1374-1382.

Mercan, M., \& Azer, A. O. (2013). The relationship between economic growth and income distribution in Turkey and the Turkish republics of central Asia And Caucasia: Dynamic panel data analysis with structural breaks. Eurasian Economic Review, 3(2), 165-182.

Moyer, J. D., \& Hughes, B. B. (2012). Icts: Do they contribute to increased carbon emissions? Technological Forecasting and Social Change, 79, 919-931.

Mrabet, Z., \& Alsamara, M. (2017). Testing the Kuznets curve hypothesis for Qatar: A comparison between carbon dioxide and ecological footprint. Renewable and Sustainable Energy Reviews, 70, 1366-1375.

Odhiambo, N. M. (2009a). Electricity consumption and economic growth in South Africa: A trivariate causality test. Energy Economics, 31(5), 635-640.

Odhiambo, N. M. (2009b). Energy consumption and economic growth nexus in Tanzania: An ARDL bounds testing approach. Energy Policy, 37(2), 617-622.

OECD, (2010). Greener and Smarter, ICTS, the Environmental and Climate Change Report.

Ozcan, B., \& Apergis, N. (2018). The impact of internet use on air pollution: Evidence from emerging countries. Environmental Science and Pollution Research, 2018(25), 4174-4189.

Ozturk, I., \& Acaravci, A. (2010). CO2 emissions, energy consumption and economic growth in Turkey. Renewable and Sustainable Energy Reviews, 14(9), 3220-3225. 
Ozturk, I., Al-Mulali, U., \& Saboori, B. (2016). Investigating the environmental Kuznets curve hypothesis: The role of tourism and ecological footprint. Environmental Science and Pollution Research, 23(2), 1916-1928.

Pesaran, M. H. (2004). General diagnostic tests for cross section dependence in panels. IZA Discussion Paper, 1240

Pesaran, M. H. (2006). Estimation and inference in large heterogeneous panels with a multifactor error structure. Econometrica, 74(4), 967-1012.

Raheem, I. D., Tiwari, A. K. and Balsalobre-Lorente, D. (2019). The role of ICT and financial development on $\mathrm{CO} 2$ emissions and economic growth, African Governance and Development Institute Working Paper, WP/19/058

Romm, J. (2002). The internet and the new energy economy. Resources, Conservation and Recycling, 36, $197-210$.

Sadorsky, P. (2012). Information communication technology and electricity consumption in emerging economies. Energy Policy, 48, 130-136.

Salahuddin, M., \& Alam, K. (2015). Internet usage, electricity consumption and economic growth in Australia: A time series evidence. Telematics and Informatics, 32, 862-878.

Salahuddin, M., Alam, K., \& Ozturk, İ. (2016). The Effects of internet usage and economic growth On CO2 emissions in OECD countries: A panel investigation. Renewable and Sustainable Energy Reviews, 62, 1226-1235.

Shabani, Z., \& Shahnazi, R. (2019). Energy consumption, carbon dioxide emissions, information and communications technology, and gross domestic product in iranian economic sectors: A panel causality analysis. Energy, 169, 1064-1078.

Shafik, N. (1994). Economic development and environmental quality: An econometric analysis. Oxford Economic Papers, 46, 757-773.

Shahbaz, M., Hye, Q. M. A., Tiwari, A. K., \& Leitao, N. C. (2013). Economic growth, energy consumption, financial development, international trade and $\mathrm{CO} 2$ emissions in Indonesia. Renewable and Sustainable Energy Reviews, 25, 109-121.

Shahbaz, M., Tiwari, A. K., \& Nasir, M. (2013b). The effects of financial development, economic growth, coal consumption and trade openness on CO2 emissions in South Africa. Energy Policy, 61, 1452-1459.

Soytas, U., Sari, R., \& Ewing, B. T. (2007). Energy consumption, income, and carbon emissions in the United States. Ecological Economics, 62(3), 482-489.

Stern, D. I. (1998). Progress on the environmental Kuznets curve? Environment and Development Economics, 3, 173-196.

Stern, D. I. (2004). The rise and fall of the environmental kuznets curve. World Development, 32, 1419-1438.

Stern, D. I., Common, M. S., \& Barbier, E. B. (1996). Economic growth and environmental degradation: The environmental kuznets curve and sustainable development. World Development, 24(7), 1151-1160.

Suri, V., \& Chapman, D. (1998). economic growth, trade and energy: Implications for the environmental kuznets curve. Ecological Economics, 25, 195-208.

Takase, K., \& Murota, Y. (2004). The impact of IT investment on energy: Japan and US comparison in 2010. Energy Policy, 32, 1291-1301.

Tiwari, A. K., Shahbaz, M., \& Hye, Q. M. A. (2013). The environmental kuznets curve and the role of coal consumption in India: Cointegration and causality analysis in an open economy. Renewable Sustainable Energy Review, 18, 519-527.

Toffel, M. W., \& Horvath, A. (2004). Environmental implications of wireless technologies: News delivery and business meetings. Environmental Science and Technology, 38, 2961-2970.

United Nations (2015). Paris Climate Agreement. Retrieved From. https://Unfccc.Int/Sites/Default/Files/Engli sh_Paris_Agreement.Pdf

Webb, M., et al. (2008). SMART 2020: Enabling the low carbon economy in the information age. Climate Group, 1(1), 1.

Wyckoff, A. M., \& Roop, J. M. (1994). The embodiment of carbon in imports of manufactured products: Implications for international agreements on green-house gas emissions. Energy Policy, 22, 187-194.

Zhang, C., \& Liu, C. (2015). The impact of ICT industrial CO2 emissions: A regional analysis in China. Renewable Sustainable Energy Review, 44, 12-19.

Publisher's Note Springer Nature remains neutral with regard to jurisdictional claims in published maps and institutional affiliations. 